\title{
Mefenamate, an Agent that Fails to Attenuate Experimental Cerebral Infarction
}

\author{
John J. Kelly, Roland N. Auer
}

\begin{abstract}
Background: Blockade of nonselective cation channels is a potential therapeutic approach that has not been attempted in cerebral ischemia, in spite of the ability of these channels to allow cellular calcium influx into neurons. Fenamates are a class of molecules that block these channels, and many congeners are also anti-inflammatory and free radical scavenging. These three mechanisms may contribute to brain damage in ischemia. Methods: Pretreatment or posttreatment with mefenamate $(30 \mathrm{mg} / \mathrm{kg}) \mathrm{was}$ evaluated in a temperature-controlled rat transient focal ischemia model. Quantitative histopathology on 26 coronal sections allowed determination of tissue necrosis and tissue atrophy at one week survival. Results: Neither pre- nor postischemic administration of a dose previously shown effective in preventing epileptic neuronal necrosis was found to reduce necrosis in cortex, nor in any subcortical structures. Conclusions: We conclude that nonselective cation channel blockade with mefenamate affords no neuroprotection in this model. Publication bias against negative studies exists in the literature, but we here report negative findings due to the multiple potentially positive actions of the drug. Closer examination of the effects of the molecule, however, reveals several potentially negative effects as well. We conclude there may be inherent weakness in pharmacologic monotherapy, even with molecules having protean potentially beneficial effects. This conclusion seems to have been borne out by the results of recent clinical trials.
\end{abstract}

RÉSUMÉ: Le méfénamate, un agent qui n'atténue pas l'infarcissement cérébral expérimental. Contexte: Le blocage des canaux cationiques non sélectifs est une approche thérapeutique potentielle qui n'a pas été tentée dans l'ischémie cérébrale malgré la capacité qu'ont ces canaux de permettre l'influx de calcium cellulaire dans les neurones. Les fénamates sont une classe de molécules qui bloquent ces canaux et plusieurs d'entre eux sont également anti-inflammatoires et anti-radicalaires. Ces trois mécanismes peuvent contribuer au dommage cérébral dans l'ischémie. Méthodes: Le prétraitement ou le post-traitement par le méfénamate $(30 \mathrm{mg} / \mathrm{kg})$ a été évalué dans un modèle murin d'ischémie focale transitoire sous température contrôlée. L'histopathologie quantitative de 26 sections coronales a permis d'identifier la nécrose tissulaire et l'atrophie après une semaine de survie. Résultats: Ni l'administration pré ou post ischémie n'a diminué la nécrose du cortex ou de structures sous-corticales. Conclusions: Nous concluons que le blocage de canaux cathioniques non sélectifs au moyen du méfénamate ne confère aucune neuroprotection chez ce modèle. Il existe dans la littérature un biais de publication contre les études dont les résultats sont négatifs. Nous rapportons ici des résultats négatifs à cause des multiples effets positifs potentiels de ce médicament. Cependant, un examen plus poussé des effets de cette molécule révèle également plusieurs effets négatifs potentiels. Nous concluons qu'il existe peut-être des faiblesses inhérentes à la monothérapie pharmacologique, même avec des molécules qui ont des effets bénéfiques potentiels protéiformes. Les résultats d'essais cliniques récents semblent appuyer cette conclusion.

Can. J. Neurol. Sci. 2003; 30: 259-262

Nonselective cation channels are ubiquitous in a variety of tissues including the central nervous system (CNS), ${ }^{1}$ and their activation can lead to cell death. ${ }^{2}$ Overactivation of these channels may play a role in pathological processes related to intracellular calcium accumulation. ${ }^{3}$ Ischemic cell death in stroke is believed in part to involve influx of calcium into neurons. ${ }^{4}$ Although blockade of agonist-gated and voltage gated L-type calcium channels has been studied in models of cerebral ischemia, with some therapeutic successes, ${ }^{5}$ blockade of nonselective cation channels has not been evaluated.

Mefenamic acid ( $\mathrm{N}-(2-3$,xylyl)-anthranilic acid) is a CNSpenetrating nonsteroidal anti-inflammatory drug possessing analgesic/antipyretic actions, that also blocks calcium-activated nonselective cation (CAN) channels. ${ }^{6}$ These CAN channels have the ability to maintain a depolarized state for extended periods of time, possibly because these channels do not inactivate, and are voltage independent. ${ }^{7}$ Experiments studying potential epileptic mechanisms in the hippocampal slice suggest that CAN channels may be linked to $\mathrm{N}$ and L-type calcium channels in neurons, ${ }^{8}$ producing a positive feedback loop which allows continued calcium influx into a cell. The resulting depolarized state would cause the voltage sensitive calcium channels to remain activated. The occurrence of spreading depression may be the result of

From the Department of Pathology \& Laboratory Medicine, University of Calgary, Calgary, AB Canada.

RECEIVED MAY 15, 2002. ACCEPTED IN FINAL FORM JANUARY 9, 2003. Reprint requests to: Roland N. Auer, Dept. of Pathology and Laboratory Medicine, University of Calgary, 3330 Hospital Drive NW, Calgary, Alberta, Canada T2N 4N1 
these mechanisms. In cerebral ischemia, spreading depressionlike depolarization waves occur. ${ }^{9}$ These considerations suggest CAN channels as attractive potential therapeutic targets in cerebral ischemia.

A second possible target for intervention in the treatment of stroke is the potentially damaging inflammatory response. ${ }^{10-12}$ Since mefenamic acid is anti-inflammatory, ${ }^{13}$ this further suggested to us that this agent should have potential as a neuroprotectant in cerebral ischemia.

A third mechanism of ischemic damage that is potentially affected is free radical production, by scavenging of nitric oxide radicals by mefenamic acid. ${ }^{14}$ With three separate modes of potentially beneficial action, we deemed mefenamic acid worthy of examination for neuroprotective effects in a temperaturecontrolled ischemia model that mimicks ischemic stroke.

\section{MATERIALS AND METHODS}

Fed male Wistar rats (320-390 g; n=30) were subjected to focal ischemia using a modified version of the intraluminal filament model for 100 minutes, at a blood pressure of $80 \mathrm{~mm}$ Hg. ${ }^{15}$ Mefenamic acid was prepared by dissolving $1.1 \mathrm{mg}$ in $1 \mathrm{ml}$ of a balanced physiologic 5-ion solution containing $140 \mathrm{mM}$ $\mathrm{Na}^{+}, 4 \mathrm{mM} \mathrm{K}^{+}, 2.1 \mathrm{mM} \mathrm{Mg}^{++}, 1.44 \mathrm{mM} \mathrm{Ca}^{++}, 141.3 \mathrm{mM} \mathrm{Cl}^{-}$and $9.54 \mathrm{mM}$ HEPES buffer. $\mathrm{NaOH}$ was added for dissolution of the drug and to adjust the $\mathrm{pH}$ to 7.8 . The solution was run through a bacterial filter and stored at $4^{\circ} \mathrm{C}$. Mefenamic acid $(30 \mathrm{mg} / \mathrm{kg})$ or saline was given by intraperitoneal injection, either 45 minutes prior to ischemia or 20 minutes after ischemia, and was continued for three days at eight hour intervals until nine intraperitoneal injections had been given. Each of the three groups (control (untreated), pretreatment, posttreatment) contained ten animals, and mortality was zero in all three groups.

To induce focal brain ischemia, rats were initially anesthetized under $4 \%$ halothane for intubation and were then ventilated on a $7: 3 \mathrm{~N}_{2} \mathrm{O}: \mathrm{O}_{2}$ mixture with $1 \%$ halothane (range: $0.5-2 \%$ ), during which a catheter was inserted into the tail artery to measure blood pressure. A lateral neck incision was made and the right common carotid artery was located at the bifurcation into the internal and external carotid arteries. The external carotid artery was dissected free, clamped at the bifurcation of the common carotid and then ligated, leaving a stump. Into this external carotid artery stump, a $25 \mathrm{~mm}$ length of 3-0 suture was inserted and guided up the internal branch of the carotid artery until a feeling of faint resistance was encountered, usually at 21$22 \mathrm{~mm}$. Occlusion duration was 100 minutes during which time blood pressure was regulated to $80 \mathrm{mmHg}$ by varying the halothane concentration. Halothane may not affect ischemic damage in the absence of hypothermia. ${ }^{16,17}$
Head temperature was monitored using a tympanic membrane probe inserted into the middle ear. Body temperature was monitored using a rectal probe. Both head and body temperatures were regulated to $37^{\circ} \mathrm{C}$ using a heating blanket underneath the animal and by varying the distance of an overhead lamp. Blood gases, $\mathrm{pH}$, glucose and hematocrit were measured pre-ischemia, during ischemia and postischemia. Blood glucose was measured, but not regulated with insulin, in order to avoid an effect of insulin itself in ischemia. ${ }^{18,19}$

After one week survival the animals were injected with pentobarbital $(0.5 \mathrm{ml} / 100 \mathrm{~g})$ and transthoracic perfusion fixation was carried out through the ascending aorta via the left ventricle. After a brief rinse of the cerebral circulation with normal saline, $4 \%$ phosphate buffered formaldehyde was perfused and the brain was removed the next day and placed in fixative. Coronal brain slices $3 \mathrm{~mm}$ thick were then cut, and dehydrated in graded ethanols. After clearing in xylol, embedding in paraffin, and $6 \mu \mathrm{m}$ thick sectioning at $500 \mu \mathrm{m}$ intervals, 26 equispaced sections were chosen for quantitation from bregma -2.2 to $-14.7 \mathrm{~mm}$. Sections were stained with hematoxylin and eosin, and damage was quantitated using a microscope connected to a computerized image analysis system. Four polygons were traced: cortical and subcortical pan-necrosis (infarction), and both ipsilateral and contralateral hemisphere. Atrophy, the difference between the two hemispheres, was calculated by subtracting ipsilateral from contralateral area. Total damage (tissue lost) was calculated by summating cortical necrosis, subcortical infarction, plus atrophy. Total damage was then graphed as percent of the opposite hemisphere, thus giving damage volumes normalized for the size of that hemisphere, obviating variation due to tissue shrinkage and different animal size. Power analysis (SigmaStat, SPSS Inc.) showed that with our sample size $(\mathrm{n}=10)$ and standard deviation (see Figure 1) we would be able to detect a $16 \%$ difference in infarct size at $\alpha=0.05$ and $\beta=0.80$ probability levels. Cerebral blood flow measurements have previously been made in this model and validate the degree of ischemia ${ }^{20}$ and the consistency of the resulting infarcts. ${ }^{15}$ The protocol was reviewed and approved by the local Animal Care Committee.

\section{ReSUlts}

Physiological parameters, including animal weight, blood glucose, $\mathrm{pO}_{2}, \mathrm{pCO}_{2}, \mathrm{pH}$, hematocrit, head temperature and body temperature, from pre, during and postischemia are displayed in the Table. No significant differences exist between the three groups in any of the parameters. However, a number $(n=7)$ of animals in the treated groups demonstrated minor, self-limiting seizures throughout the three day period of administration of mefenamic acid. These were characterized by whisker twitching

Table: Physiologic parameters

\begin{tabular}{|c|c|c|c|c|c|c|c|c|c|}
\hline & $\begin{array}{l}\text { Weight } \\
\text { (grams) }\end{array}$ & $\begin{array}{l}\text { Glucose } \\
(\mathrm{mM})\end{array}$ & $\begin{array}{l}\text { MABP } \\
(\mathrm{mm} \mathrm{Hg})\end{array}$ & $\begin{array}{l}\text { Temp } \\
\text { (tympanic) }\end{array}$ & $\begin{array}{l}\text { Temp } \\
\text { (rectal) }\end{array}$ & $\mathrm{pH}$ & $\mathrm{pCO}_{2}$ & $\mathrm{pO}_{2}$ & $\begin{array}{l}\text { Hematocrit } \\
(\%)\end{array}$ \\
\hline Untreated & $358 \pm 7$ & $6.4 \pm 0.2$ & $80.1 \pm 0.8$ & $37.02 \pm 0.01$ & $37.07 \pm 0.04$ & $7.40 \pm 0.01$ & $37.8 \pm 1.4$ & $112.7 \pm 2.7$ & $44.3 \pm 0.7$ \\
\hline Pretreated & $356 \pm 5$ & $6.2 \pm 0.3$ & $78.1 \pm 1.3$ & $37.03 \pm 0.01$ & $37.08 \pm 0.04$ & $7.39 \pm 0.01$ & $37.3 \pm 1.5$ & $117.1 \pm 3.4$ & $43.4 \pm 0.7$ \\
\hline Posttreated & $351 \pm 5$ & $6.4 \pm 0.3$ & $79.6 \pm 0.6$ & $37.03 \pm 0.01$ & $37.00 \pm 0.04$ & $7.40 \pm 0.01$ & $37.1 \pm 1.2$ & $117.6 \pm 3.8$ & $44.3 \pm 0.7$ \\
\hline
\end{tabular}




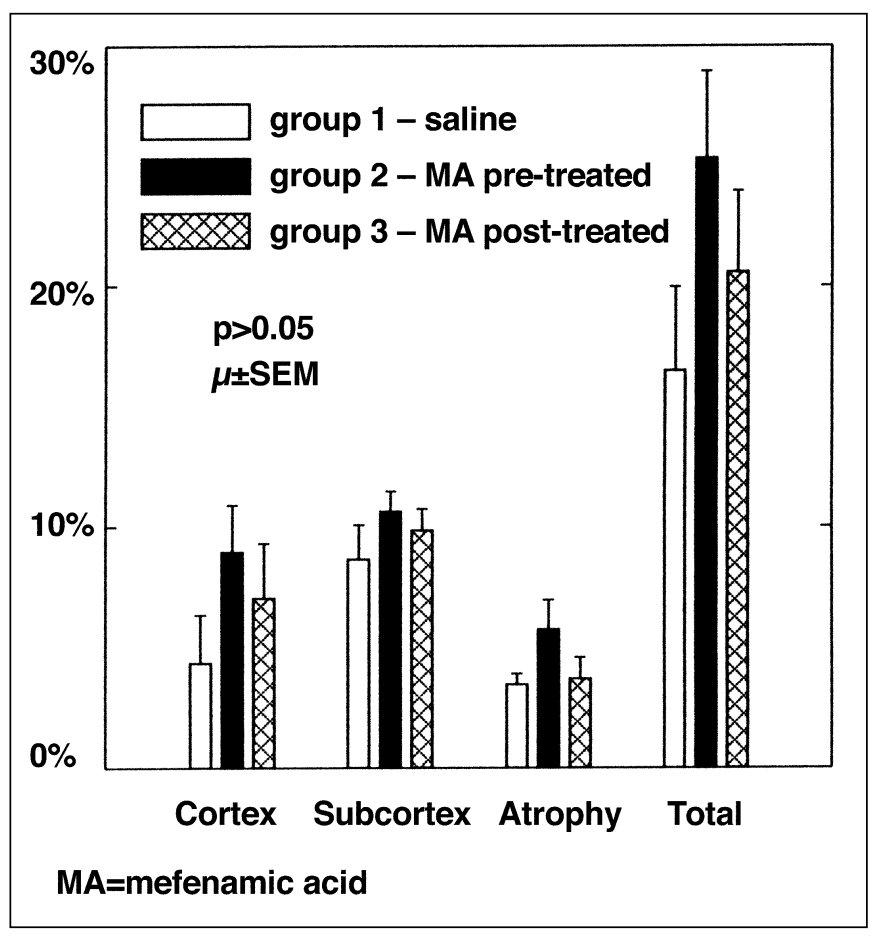

Figure: Infarct data, one week post focal ischemia, shown as a percent of the contralateral hemisphere. The subcortex includes the area of white matter, striatum and diencephalic structures that were necrotic.

and minor, nonviolent, involuntary limb movements, lasting a maximum of a few seconds. No animals receiving saline had seizures.

The Figure presents the infarct data as percent of the hemisphere. Cortical necrosis, subcortical necrosis, atrophy and total damage were not significantly different in the three groups.

\section{Discussion}

Mefenamic acid is marketed by Parke-Davis as Ponstan ${ }^{\circledR}$, and has been used in the treatment of dysmenorrhea, menorrhagia and migraine. ${ }^{21}$ There are a number of positive effects of mefenamate which would be expected to ameliorate ischemic brain damage. Mefenamate penetrates the CNS and blocks nonselective cation channels. ${ }^{6-8}$ Mefenamate is also a nonsteroidal anti-inflammatory agent which blocks cycloxygenase, the enzyme which catalyzes the first reaction on the pathway of oxidative arachidonic acid metabolism to thromboxane A2 and prostacyclin. ${ }^{22}$ We obviated hypothermia, but anti-inflammatory drugs have been reported to be neuroprotective, when hypothermia is allowed to occur. ${ }^{23}$

In addition to channel blockade and anti-inflammatory action, free radical scavenging provides a third potential mechanism of neuroprotective action. Mefenamate is neuroprotective in vitro by directly scavenging potentially damaging NO radicals. ${ }^{14}$

The negative results warrant explanation in light of multiple potentially protective mechanisms of action of this drug. Mefenamate has been shown to lower seizure threshold, ${ }^{24}$ accounting for the minor seizures we observed in the treated animals. Seizures of a global type are detrimental in ischemia ${ }^{25}$ but here were very mild and self-limiting. Their occurrence in the present study parenthetically indicates CNS penetration of the drug. Although seizures might have cancelled other, neuroprotective actions of the drug, our chosen dose was near the $\mathrm{ED}_{50}$ neuroprotective dose against neuronal necrosis from pilocarpineinduced status epilepticus. ${ }^{26}$ No trend toward any effect was seen, and this was deemed not to warrant dose-response sudies.

Mefenamate has also been shown to cause calcium release from intracellular stores ${ }^{27}$ and affects calcium-activated large conductance potassium $\left(\mathrm{K}_{\mathrm{Ca}}\right)$ channels, ${ }^{28}$ both of which might be detrimental in ischemia.

Following ischemia, cortical spreading depression (CSD) occurs. ${ }^{9,29}$ By itself, spreading depression does not cause neuronal injury ${ }^{30}$ in normal brain but it may render neurons more vulnerable ${ }^{31}$ in ischemic brain, and may contribute to neuronal damage in tissue surrounding the infarct, or distantly. ${ }^{32}$ Prevention of CSD has been deemed essential if adequate recovery of the neurons is to occur following ischemia. ${ }^{33}$ In this study, it is not possible to determine whether mefenamic acid had any effect on CSD, although nonselective cation channels may be involved in CSD. ${ }^{8}$

We here report negative findings to avoid strategies that duplicate those already attempted in ischemic neuroprotection. Also, importantly, we wish to obviate negative, costly clinical trials $^{34,35}$ based on a small number of selectively positive results in the experimental literature. ${ }^{36}$ Single drug therapy, even with a molecule having multiple beneficial actions, may have an inherent disadvantage. A given drug may not affect the multiple other mechanisms in the ischemic cascade. ${ }^{4}$ Such mechanisms may be overwhelming and could be unaffected by a single drug. These considerations make it necessary to consider multi-drug therapy, or a combination of pharmacologic and effective nonpharmacologic measures ${ }^{37,38}$ in treating brain ischemia.

\section{REFERENCES}

1. Partridge LD, Valenzuela CF. Block of hippocampal CAN channels by flufenamate. Brain Res 2000;867:143-148.

2. Estacion M, Schilling WP. Blockade of maitotoxin-induced oncotic cell death reveals zeiosis. BMC Physiol 2002;2:2-13.

3. Partridge LD, Müller TH, Swandulla D. Calcium-activated nonselective channels in the nervous system. Brain Res Rev 1994; 19:319-325.

4. Siesjö BK, Bengtsson F. Calcium fluxes, calcium antagonists, and calcium-related pathology in brain ischemia, hypoglycemia, and spreading depression: a unifying hypothesis. J Cereb Blood Flow Metab 1989;9:127-140.

5. Auer RN. Calcium channel antagonists in cerebral ischemia: a review. Drug Dev 1993;2:307-317.

6. Gogelein H, Dahlem D, Englert HC, Lang HJ. Flufenamic acid, mefenamic acid and niflumic acid inhibit single nonselective cation channels in the rat exocrine pancreas. FEBS Lett 1990;268:79-82.

7. Partridge LD, Swandulla D. Single Ca-activated cation channels in bursting neurons of Helix. Pflügers Arch 1987;410:627-631.

8. Fraser DD, MacVicar BA. Cholinergic-dependent plateau potential in hippocampal CA1 pyramidal neurons. J Neurosci 1996;16:4113-4128.

9. Mutch WAC, Hansen AJ. Extracellular $\mathrm{pH}$ changes during spreading depression and cerebral ischemia: mechanisms of brain pH regulation. J Cereb Blood Flow Metab 1984;4:17-27.

10. Chopp M, Zhang RL, Chen $\mathrm{H}$, et al. Postischemic administration of an anti-mac-1 antibody reduces ischemic cell damage after transient middle cerebral artery occlusion in rats. Stroke 1994;25:869-876. 
11. Clark WM, Madden KP, Rothlein R, Zivin JA. Reduction of central nervous system ischemic injury in rabbits using leukocyte adhesion antibody treatment. Stroke 1991;22:877-883.

12. Mori E, del Zoppo GJ, Chambers JD, Copeland BR, Arfors K-E. Inhibition of polymorphonuclear leukocyte adherence suppresses no-reflow after focal cerebral ischemia in baboons. Stroke 1992;23:712-718.

13. Di Rosa M, Papadimitriou JM, Willoughby DA. A histopathological and pharmacological analysis of the mode of action of nonsteroidal anti-inflammatory drugs. J Pathol 1971;105:239256.

14. Asanuma M, Nishibayashi-Asanuma S, Miyazaki I, Kohno M, Ogawa N. Neuroprotective effects of nonsteroidal antiinflammatory drugs by direct scavenging of nitric oxide radicals. J Neurochem 2001;76:1895-1904.

15. Zhu CZ, Auer RN. Graded hypotension and MCA occlusion duration: effect in transient focal ischemia. J Cereb Blood Flow Metab 1995; 15:980-988.

16. Ridenour TR, Warner DS, Todd MM, Gionet TX. Comparative effects of propofol and halothane on outcome from temporary middle cerebral artery occlusion in the rat. Anesthesiology 1992;76:807-812.

17. Warner DS, McFarlane C, Todd MM, Ludwig P, McAllister AM. Sevoflurane and halothane reduce focal ischemic brain damage in the rat. Possible influence on thermoregulation. Anesthesiology 1993;79:985-992.

18. Hamilton MG, Tranmer BI, Auer RN. Insulin reduction of cerebral infarction due to transient focal ischemia. J Neurosurg 1995;82:262-268.

19. Voll CL, Auer RN. Insulin attenuates ischemic brain damage independent of its hypoglycemic effect. J Cereb Blood Flow Metab 1991;11:1006-1014.

20. Miyamoto O, Auer RN. Hypoxia, hyperoxia, ischemia and brain necrosis. Neurology 2000;54:362-371.

21. Peatfield RC, Petty RG, Rose FC. Double blind comparison of mefenamic acid and acetaminophen (paracetamol) in migraine. Cephalalgia 1983;3:129-134

22. Saeed SA, Warren BT. On the mode of action and biochemical properties of anti-inflammatory drugs. I. Biochem Pharmacol 1973;22:1965-1969.

23. Coimbra C, Drake M, Boris-Möller F, Wieloch T. Long-lasting neuroprotective effect of postischemic hypothermia and treatment with an anti-inflammatory/antipyretic drug. Evidence for chronic encephalopathic processes following ischemia. Stroke 1996;27:1578-1585.
24. Wallenstein MC. Differential effects of prostaglandin synthetase inhibitors on EEG in rat. Eur J Pharmacol 1985;111:201-209.

25. Voll CL, Auer RN. Postischemic seizures and necrotizing ischemic brain damage: neuroprotective effect of postischemic diazepam and insulin. Neurology 1991;41:423-428.

26. Ikonomidou-Turski C, Cavalheiro EA, Turski L, et al. Differential effects of nonsteroidal anti-inflammatory drugs on seizures produced by pilocarpine in rats. Brain Res 1988;462:275-285.

27. Poronnik P, Ward MC, Cook DI. Intracellular $\mathrm{Ca}^{2+}$ release by flufenamic acid and other blockers of the nonselective cation channel. FEBS Lett 1992;296:245-248.

28. Ottolia M, Toro L. Potentiation of large conductance KCa channels by niflumic, flufenamic, and mefenamic acids. Biophys $\mathrm{J}$ 1994;67:2272-2279.

29. Vyskocil F, Kritz N, Bures J. Potassium-selective microelectrodes used for measuring the extracellular brain potassium during spreading depression and anoxic depolarization in rats. Brain Res 1972;39:255-259.

30. Nedergaard M, Hansen AJ. Spreading depression is not associated with neuronal injury in the normal brain. Brain Res 1988;449:395-398.

31. Gidö G, Kristián T, Katsura K, Siesjö BK. The influence of repeated spreading depression-induced calcium transients on neuronal viability in moderately hypoglycemic rats. Exp Brain Res 1994;97:397-403.

32. Dietrich WD, Feng ZC, Leistra H, Watson BD, Rosenthal M. Photothrombotic infarction triggers multiple episodes of cortical spreading depression in distant brain regions. J Cereb Blood Flow Metab 1994;14:20-28.

33. Hossmann K-A. Viability thresholds and the penumbra of focal ischemia. Ann Neurol 1994;36:557-565.

34. Grotta J. Why do all drugs work in animals but none in stroke patients? 2. Neuroprotective therapy. J Intern Med 1995;237:8994.

35. Anonymous. Recommendations for standards regarding preclinical neuroprotective and restorative drug development. Stroke 1999;30:2752-2758

36. Auer RN. Points of view. Early application of the results of animal experimentation to clinical trials: Con. J Neurosurg Anesthesiol 1996;8:73-77.

37. Auer RN. Nonpharmacologic (physiologic) neuroprotection in the treatment of brain ischemia. Ann NY Acad Sci 2001;939:271282.

38. Flynn E, Auer RN. Eubaric hyperoxemia and experimental cerebral infarction. Ann Neurol 2002; 52:566-572. 